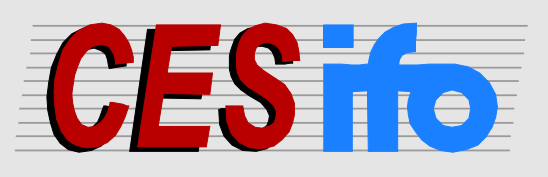

\title{
Working
}

Papers

www.cesifo.org/wp

\section{Roles of Social Conformity in Deviance in Poverty: A Study on Working Poverty and Educational Investment in Bangladesh}

\author{
Biswa Nath Bhattacharyay \\ Partha Gangopadhyay \\ Mustafa A. Rahman
}

CESIFO WORKING PAPER NO. 4395

CATEGORY 5: ECONOMICS OF EDUCATION

SEPTEMBER 2013

\footnotetext{
An electronic version of the paper may be downloaded

- from the SSRN website:

- from the RePEc website:

- from the CESifo website:

WWW.SSRN.com

www.RePEc.org

www.CESifo-group.org/wp
}

\section{CESifo}




\title{
Roles of Social Conformity in Deviance in Poverty: A Study on Working Poverty and Educational Investment in Bangladesh
}

\begin{abstract}
In recent decades the Indian subcontinent has displayed remarkable invariance in the incidence of working poverty despite strong economic performance. It is widely held that education can rescue households from various types of poverty traps created by information problems and incorrect expectations. Yet very little is known about the motivation of the working poor in acquiring education. From a field study conducted in Bangladesh, this paper provides invaluable insights for the first time, to our best understanding, into the factors that shape the decision of a poor household to care about and respond to educational decisions of others in one's community. Based on the "Choice-Theoretic Framework of Rational Emulation and Deviance”, this paper empirically explains why some households choose to copy others, while some choose deviance even though social deviance in acquiring education can throw subjects into abject poverty. In particular, the paper examines the determinants of the (individual) educational expenditure of a household sheltering the working poor.
\end{abstract}

JEL-Code: L000, L130.

Keywords: social conformity/copying, deviance, poverty, education, Asia, India and Bangladesh.

\author{
Biswa Nath Bhattacharyay \\ FORE School of Management \\ 700156 Newtown, Kolkata West Bengal / India \\ dr_biswa@yahoo.com
}

Partha Gangopadhyay

University of Western Sydney

Sydney / Australia

p.gangopadhyay@uws.edu.au
Mustafa A. Rahman

North South University of Bangladesh

Dhaka / Bangladesh 


\section{Introduction}

Since the new millennium most of the economies in the Indian subcontinent have registered significant economic growth. In the business world we now hear about the unshackling of the 'caged tiger', among other things, about the prospect of the economies in the Indian subcontinent as a future powerhouse of the globe. Under the rummage of a 'hype and oversimplification', a strong view has emerged that the economic miracle of the region is propelled by the informal sector in the subcontinent dotted with severe forms of working poverty (see Bardhan, 2010) ${ }^{1}$. Several important observations are in order about the informal sector: first, from the national household data in the subcontinent, we now know that the decline in extreme poverty was inadequate in 1993-2010. Secondly, social indicators like child health were and still are dangerously alarming in many nations ${ }^{2}$. Thirdly, the growth rate in agriculture that absorbs most of the working poor has steadily declined since the new millennium, which is largely caused by continuing decline in public investment in farm infrastructure. Finally, economic management has failed to address the problems associated with the quality of institution and governance, which has created huge barriers for the provision of merit goods, local public goods and social services - as these economies have gotten richer people are eating less (Banerjee and Duflo, 2011). There is no gainsaying to the fact that the services sector is the main driver of economic growth in the Indian subcontinent. Yet the informal sector is the most dominant form of economic organisation in the services sector as two-thirds of the services are in the informal sector ${ }^{3}$. With declining

\footnotetext{
${ }^{1}$ In the Indian context, Bardhan (2010) admits that economic reforms have made the corporate sector more ibrant and competitive, yet the bulk of the Indian economy remains rather disconnected from the corporate sector. As an example, nearly 95\% of the Indian labour force is absorbed by the non-corporate sector. The much-celebrated info-tech sector accounts for about $1 \%$ of the labour force. Financial and business services and telecommunications, where the economic reforms are mostly visible, account for less than $25 \%$ of the output of the Indian services sector.

${ }^{2}$ There is a growing criticism that national and state governments have failed to provide for social service delivery, education, health, child nutrition, drinking water, irrigation water etc. for the poor especially in the Indian society.
} 
public goods in infrastructure, power and roads, and inadequate provisions of merit goods along with a declining agrarian sector - the informal sector will continue facing an uphill battle in providing escape routes for the poor.

The economic situation over the last two decades or so in several developing economies including Bangladesh has created a new social category of people known as the working poor, those who are employed but remain below a defined poverty threshold. Despite the popular belief that those who work hard should not remain poor, there exists a vast reserve of labour who still remains impoverished. This phenomenon is prevalent in both middle income and low income countries of Asia, including Bangladesh. The main thrust of our work is to argue that working poverty in the informal sector is driven by "unfair" wages and households can escape the poverty trap by investing in education. Our intuition is closely related to the powerful observation of Sen (2000) that poverty and social exclusion can be caused by social inclusion - an apparent contradiction in terms - that is based on "unfair terms". In other words, in the era of globalisation working poverty has created a new class of workers in developing nations who are "absolute poor" despite their regular streams of earnings from the labour market. Poverty of these workers is caused by unfair terms in the informal sector labour market. They suffer from poverty traps created by imperfect information and incorrect expectations, while education plays a significant role in dismantling poverty traps (see Banerjee and Duflo, 2011). The unanswered question in this context is what determines the (individual) educational expenditure of a household sheltering the working poor. This paper derives a framework to answer this question. We develop the framework in Section 2 and explain the findings from the field study in Section 3. In Section 4 we relate our findings to the literature on poverty, social exclusion and destitution. We conclude in Section 5.

\footnotetext{
${ }^{3}$ More than $90 \%$ of the workforce of the region belongs to the informal labour market with virtual absence of labour unions and accompanying safety nets. It is important to stress that the continuing prosperity in the regional economy has created significant inequality, both vertical and horizontal - the informal sector being on the wrong side of the economic and social divide in the region.
} 


\section{The Choice-Theoretic Framework of Rational Emulation and Deviance: Educational Expenditure at the Household Level}

Educational expenditure is an important factor for poverty reduction. Poverty is positively related to the level of education: that is, poverty lessens as the level of education increases. We assume that individual households care about education as well as its relative position, or 'status', in terms of educational expense and thereby construct a simple model of decision-making on educational expenditure. The model is embedded in a choice-theoretic framework for a class of models developed by Akerlof (1980), Jones (1984) and Kandel and Lazear (1992). The idea originates from the so-called comparison theory, initiated by early social thinkers like Marx (1849), James (1891) and Durkheim (1893), which highlights the human proclivity to compare their holdings of goods to the level of holdings of a representative agent from one's reference group (see Runciman, 1961; Blau, 1964 and Jasso, 2001). In order to highlight the role of status in economic behaviour Frank (1984a, 1984b) examines consumer behaviour when they signal income by consumption and also when workers care for their prestige in a workplace. Following the elegant models of Clark and Oswald (1996; 1998), we posit that household i's utility function is given by:

$$
\Pi_{i}\left(K_{i}, K^{*}\right)=w V\left(K^{*}-K_{i}\right)+(1-w) U\left(K_{i}\right)-L\left(K_{i}\right)
$$

The overall utility function of the household is $\Pi_{i}, K_{i}$ is its educational expense and $K^{\star}$ is the educational expense of the reference group, $\mathrm{V}$ is the comparison utility, $\mathrm{U}$ is the direct utility from education and $L\left(\mathrm{~K}_{\mathrm{i}}\right)$ is the cost of education on the household welfare. Note that $w$ is the weight that a household accords to status, or comparison. We assume a simple cubic function to represent the comparison utility ss $^{4}$ :

$V\left(K^{*}-K_{i}\right)=\left[\left(K^{*}-K_{i}\right)^{3} / 3\right]+K_{0}$

\footnotetext{
${ }^{4}$ We provide the rationale for and the weaknesses of the cubic utility function in Appendix 1.
} 
Note $\mathrm{K}_{0}$ is a constant and we set $\mathrm{K}_{0}=0$ for deriving the following first and second order conditions.

The first order condition to maximise utility is given by:

$\Pi_{i}{ }^{\prime}\left(K_{i}, K^{*}\right)=w V^{\prime}\left(K^{*}-K_{i}\right)+(1-w) U^{\prime}\left(K_{i}\right)-L^{\prime}\left(K_{i}\right)=0$

By applying the implicit function theorem we know:

$$
\frac{\partial K_{i}}{\partial K^{*}}=\frac{2 w\left(K^{*}-K_{i}\right)}{\left[w V^{\prime \prime}\left(K^{*}-K_{i}\right)+(1-w) U^{\prime \prime}\left(K_{i}\right)-L^{\prime \prime}\left(K_{i}\right)\right]}
$$

Note that the denominator of the RHS of (4) is negative from the second order condition of maximisation of utility. Thus,

$$
\frac{\partial K_{i}}{\partial K^{*}}<0 \text { if } K^{*}>K_{i}
$$

Note that (5a) implies households to follow each other, or some form of social copying that implies social conformity (see Clark and Oswald, 1998).

$\frac{\partial K_{i}}{\partial K^{*}}>0$ if $\mathrm{K}^{*}<\mathrm{K}_{\mathrm{i}}$

From Clark and Oswald (1998) we know that (5b) implies social deviance.

\subsection{Empirical Specification: Household Choice between Social Copying vis-a-vis Social Deviance}

We posit that the decision of household $i$ to spend on education $K_{i}$ in excess of $K^{\star}$ depends on an unobservable return from education $\left(\mathrm{M}_{\mathrm{i}}\right)$, which is a latent variable that depends on a vector of explanatory variables $X\left(X_{1}, X_{2} \ldots X_{n}\right)$ in such a way that the larger the value of $M_{i}$, the greater the probability of household $i$ having $K_{i}>K^{\star}$. We write the index $M_{i}$ as a function of the explanatory variables $\mathrm{X}$ :

$\mathrm{M}_{\mathrm{i}}=\sum_{1}^{n} \beta_{i} X_{i}$ 
Then the probability that the educational expense of household $\mathrm{i}$ exceeds the reference group average $K^{*}$, expressed as $\operatorname{Pr}_{i}\left(K_{i}>K^{*}\right)$, is equivalent to the case that that the household's return from education exceeds the critical level $\left(M_{i}>M^{*}\right)$ where $M^{*}$ is the threshold, or critical, rate of return from education. The above probability is expressed as a simple Probit model:

$\operatorname{Pr}_{\mathrm{i}}\left(\mathrm{K}_{\mathrm{i}}>\mathrm{K}^{\star}\right)=\operatorname{Pr}_{\mathrm{i}}\left(\mathrm{M}^{*}<\mathrm{M}_{\mathrm{i}}\right)=\Omega\left(\sum_{1}^{n} \beta_{i} X_{i}(\mathrm{X})\right)$

$\Omega$ is the standardised normal CDF and we obtain an index of rate of return $M_{i}$ by deriving estimates of $\beta_{i}$ and expressing $M_{i}$ as:

$\mathrm{M}_{\mathrm{i}}=\Omega^{-1}\left(\sum_{1}^{n} \beta_{i} X_{i}(\mathrm{X})\right)$

We define $Z_{i}$ as the following for household $\mathrm{i}$ :

$Z_{i}=1$ if $K_{i}>K^{\star}$, otherwise $Z_{i}=0$

So (6b) implies:

$\operatorname{Pr}_{i}=\operatorname{Pr}_{i}\left(Z_{i}=X\right)=\operatorname{Pr}_{i}\left(K_{i}>K^{*}\right)=\operatorname{Pr}_{i}\left(M^{*}<M_{i}\right)=\Omega\left(\sum_{1}^{n} \beta_{i} X_{i}\right)$

Once we estimate (7a), substituting the coefficients $\beta_{i}$ s into (6a) gives the estimated values of $\mathrm{M}_{\mathrm{i}}$, which we label as $\hat{M}_{i}$ :

$$
\hat{M}_{i}=\sum_{1}^{n} \hat{\beta}_{i} X_{i}
$$

Where $\hat{\beta}_{i} s$ are the estimated values of coefficients $\beta_{i}$ from (6b). Once we have $\hat{M}_{i}$ for each i we regress $\hat{M}_{i}$ on a number of regressors $\left\{\mathrm{X}_{1}, \mathrm{X}_{2} \ldots \mathrm{X}_{\mathrm{n}}\right\}$ that are the characteristics of individual households and their interviewed members.

\subsection{Data}

Data for estimating the model have been obtained from a field survey conducted in Bangladesh in 2008-09. Data were collected from both rural and urban areas. A multi-stage 
stratified random sampling technique without replacement was used to select sample locations and respondents. Rural area means agriculture sector while urban area refers to manufacturing, transport, construction and service sector. Number of households selected from the agriculture sector was 248 while the figures were 200 from manufacturing sector, 100 from service sector, 60 from transport sector and 52 from construction sector. The households were drawn randomly proportionate to the size in the population. Thus a sample of 660 households was selected for intensive interview. We have used the expenditure on education $\left(\mathrm{K}_{\mathrm{i}}\right)$ by each household $\mathrm{i}$ for the week preceding the date of interview. We have chosen five sectors namely agriculture, manufacturing, transport, construction and services sectors. Each sector is used as a reference group. We thus have 5 values $\mathrm{K}^{\star}$ - one for each sector. The independent variables, $\left\{X_{i}\right\}$, are given in Table 1:

Table 1: Description of Independent Variables

\begin{tabular}{|c|c|}
\hline Independent Variables & Description \\
\hline AGE & Actual years attained of the subject \\
\hline $\mathrm{AGE}^{2}$ & Age*Age \\
\hline $\begin{array}{l}\text { Marital Happiness of Household } \\
\text { Head(MHAP) }\end{array}$ & $\begin{array}{l}\text { We apply the following index of conjugal } \\
\text { happiness: } 1=\text { Happily married, } 2=\text { Seeking } \\
\text { partners for happiness, } 3=\text { Widowed, } 4= \\
\text { Divorced or separated, } 5=\text { Multiple partners }\end{array}$ \\
\hline Education of the Household Head (EDU) & $\begin{array}{l}\text { Never attended schools }=0, \text { level I }-\mathrm{V}=1, \\
\text { level } \mathrm{VI}-\mathrm{VIII}=2 \text {, level IX- X=3, SSC }=4 \text {, } \\
\mathrm{HSC}=5, \text { Graduate }=6\end{array}$ \\
\hline Gender of the subject (GEN) & Male $=1$, and Female $=0$ for respondents \\
\hline FOOD & $\begin{array}{l}\text { Monthly per capita food expenditure of } \\
\text { household }\end{array}$ \\
\hline LHOLD & Land holding of household in acres \\
\hline DWATER & $\begin{array}{l}\text { Ownership of dwelling house, Owned: } 1 \text {, } \\
\text { Semi-Owned/Owning: 2, Renting: 3, Rent } \\
\text { Subsidies, 4: Others } \\
\text { Availability of Drinking Water, Pond/River:1, } \\
\text { Tubewell:2, Tap:3 }\end{array}$ \\
\hline
\end{tabular}


In order to identify multicollinearity we have calculated the correlation of the aforementioned variables and provided them in Table 2, which shows that there is no need to drop any variable:

Table 2: Correlation Matrix

\begin{tabular}{|l|l|l|l|l|l|l|l|l|}
\hline Variable & AGE & MSTAT & EDU & GEN & LHOLD & FOOD & DHOUSE & DWATER \\
\hline AGE & 1 & & & & & & & \\
\hline MHAP & .2 & 1 & & & & & & \\
\hline EDU & .40 & .40 & 1 & & & & & \\
\hline GEN & -.41 & -.41 & -.26 & 1 & & & & \\
\hline LHOLD & -.09 & -.09 & .09 & .13 & 1 & & & \\
\hline FOOD & .065 & .06 & .12 & .08 & .16 & 1 & & \\
\hline DHOUSE & -.19 & -.19 & -.24 & .17 & .02 & -.24 & 1 & \\
\hline DWATER &.- .3 & -.3 & -.24 & .29 & -.007 & -.04 & -.04 & 1 \\
\hline
\end{tabular}

\section{Empirical Findings}

Our empirical results are summarised in Table 3:

Table 3: Estimates of PROBIT Regression

\begin{tabular}{lccc}
\hline Independent variables & Coefficients & $\mathbf{z}$ & $\mathbf{p}>|\mathbf{z}|$ \\
\hline CONSTANT & -2.334 & -3.38 & 0.001 \\
AGE & 0.155 & 4.51 & 0.000 \\
AGE $^{2}$ & -0.002 & -4.69 & 0.000 \\
MHAP & -0.392 & -2.77 & 0.006 \\
EDU & 0.137 & 2.18 & 0.030 \\
GEN & 0.339 & 2.93 & 0.003 \\
LHOLD & 0.448 & 1.56 & 0.120 \\
FOOD & -2.82 & 0.005 \\
DHOUSE & -0.0093 & -0.51 & 0.610 \\
DWATER & -.0336 & 0.12 & 0.902 \\
\hline Number of observations & 0.008 & & 660
\end{tabular}


Note: Dependent Variable: Probability $\left(\mathrm{Z}_{\mathrm{i}}=1\right)$

Method: $M L$-Probit (Quadratic hill climbing)

Covariance matrix computed using second derivatives

Obs with Dep $=0$

Several important observations are in order: first, AGE of a subject has a strong positive influence on the "copying/following" behaviour in educational investment, which is also statistically significant. This sort of copying behaviour is known as positive herding. This effect is expected since agents acquire more and increasingly better information over time from their life experience to beat the developmental problems and poverty traps created by "poor information and incorrect expectations" as highlighted by Banerjee and Duflo (2011). However, the effect of AGE on positive herding in educational investment is found to be concave in nature, which increases at a diminishing rate. This suggests a possible threshold effect that indicates a critical age below which people choose to herd. Once the critical age is crossed people decide to go against the flow. However, from our empirical findings, we note that for our subjects in their working age (18-60 years), the overall effect of AGE is to induce households to positively herd on educational investment. Secondly, the declining quality of marital life of the decision-maker in a household, captured by MHAP, has a strong negative and statistically significant effect. This shows that the parental investment in their wards' education has a tendency to decline if there are marital problems in a family. In other words, there is strong evidence that marital problems can cause social deviancy, in terms of educational expenses, which can in turn compromise the future of children and lock them in poverty traps. Thirdly, we note that education of household head (EDU) has a positive and statistically significant impact on the household to adopt copying behaviour in education, 
which is a common observation in the literature on education and development. Fourthly, there is strong evidence that gender (GEN) plays a negative role in this context: surprisingly earnings by female members induce a family to "go against the flow" and invest less in education as the average expenditure on education in the reference group increases. In the migration literature, this is a well-known phenomenon - female migrants' remittances/earnings are spent less on investment and more on social consumption in comparison with the household spending patterns from the remittances of male migrants. Fifthly, land holding (LHOLD) has a positive influence on social herding in education, which is expected as a status-seeking behaviour. However, this effect is not statistically significant. Sixthly, the per capita expenditure on foods and other necessities (FOOD) has a strong adverse influence on education, which is also statistically significant. This arises since the main opportunity cost of education is FOOD in our model. One can therefore argue the food price inflation in poor countries can have a significant and lasting impact on poverty by reinforcing the poverty traps via its strong effect on social deviancy of households in acquiring education for their wards. Finally, the other two effects are small and statistically insignificant though their signs are expected from simple economic intuitions.

\section{Poverty, Economics of Social Exclusion and Human Agency: Absolute versus}

\section{Relative Poverty}

Poverty can be viewed either in absolute or relative terms. Assessing poverty in relative terms popularised the concept of relative deprivation instead of relative poverty for understanding poverty across various groups of people in the society living in different conditions. A person may fall into poverty if he/she fails to perform in the words of Sen (1983) like other people in the society. An absolutely poor person may not be deprived relatively if he/she shares the same condition as most people in the neighbourhood. The issue of relative deprivation is important from policy point of view because if it is severe then 
the policies should focus on distribution rather than growth. Kakwani (1993) and, Ravallion and Chen (1998) noted that provided constant distribution of relative income and rate of growth, it would take more time to eradicate absolute poverty in a more in-egalitarian economy than in an economy with less relative deprivation. Many of these papers examine deprivation of a worker compared to another worker across various sectors (agriculture, manufacturing, transport, construction and service) based on wages they are paid for their work. Attempt has been taken to identify determinants of deprivation using standard regression as an instrument of analysis. It is important to stress that deprivation is closely linked to social exclusion which is multifaceted in nature and arises out of personal attributes and malfunctioning of socio-political institutions of the country. In the words of Sen (1993), people are deprived because their capability set is simply not broad enough to permit them catching up. On the contrary, it may be due to structural lack of opportunities either at workplaces or in the society. Their inaccessibility to existing opportunities may be due to lack of education, skill, and financial as well as social capital. Some argue that they are alienated from the available opportunities because of imperfections in the labour and capital markets. We observe a underclass in the society emerging from stagflation in Europe in the 1970's (Lenoir 1974, Silver 1994). The underclass is a new social category that fails to participate productively in the modern economy and the society and thereby constitutes the most vulnerable and hapless section of a society. A more balanced and somewhat utilitarian view has been championed by Sen (2000),

"While the underlying idea behind the concept of social exclusion is not radically new, the growing literature on the subject has helped to enrich causal understanding and empirical analysis of certain aspects of poverty and deprivation. To be excluded from common facilities or benefits that others can certainly be a significant handicap that impoverishes the lives that individuals can enjoy. No concept of poverty can be satisfactory if it does not take adequate note of the disadvantages that arise from being excluded from shared opportunities enjoyed by others" (pp. 10). 
It is increasingly noted that the rural poverty has a special relationship with social immobility and social exclusion.

\subsection{Social Exclusion: Rural Poverty as the Latest Scourge in Developing Nations}

The usual stereotypes of agriculture in economic development are multifaceted: first, agricultural activities produce generic commodities like food by using constant returns to scale technologies. Secondly, this sector seems to lack product diversity, knowledge externalities and innovations. Thirdly, agricultural markets are mostly competitive. Fourthly, agriculture, being land-intensive, has a tendency to disperse spatially. At least, it is widely believed, there is built-in inertia in the sector that prevents dense concentration of agrarian activities in small pockets. The consequences can be of mammoth importance: the benefits of agglomeration economies, or clustering of economic activities, can bypass agriculture, which can cause significant rural poverty unless the economic progress of the industrial sector - driven by agglomeration economies - absorbs the surplus labour of the agricultural sector. In reality, most of the poor in developing economies live in the rural sector today. It is hence an important research quest to understand the causes of rural poverty in such economies. In this context, it is imperative to note that the basic forces for spatial agglomeration and trade in models of agglomeration externalities derive from non-market interactions that yield increasing returns external to firms. They usually include knowledge spillovers, business communications, face-to-face communication, and other spatial externalities.

It is only recently some new developments took place that can change the perception of agriculture and the rural economy. The most important paradigm shift has come about the role of agglomeration forces for agriculture. In a seminal work, one of the creators of the 
NEG, Fujita (2006) forcefully argues that it is possible to introduce product differentiation and consequent market power in the agricultural sector. By doing so and introducing a new and more comprehensive model in Fujita (2007), Fujita advanced a new direction of research to unravel the role of economics of agglomeration in explaining rural development, or a lack of it. The second important change took place in the very context of analysing agglomeration. Traditionally, spatial externalities have been treated in a "black box" manner that failed to highlight the actual micro-interactions giving rise to such externalities. It is only recently economists started highlighting micro interaction behaviour. Despite these advancements, we still know very little about how such behaviour leads to those aggregate external effects for the agricultural sector and whether agglomeration plays an important role in rural development and fighting rural poverty.

Eradication of poverty and rural economic development are intrinsically related. There is little scope for eradicating rural poverty by opening up an economy to global market forces. Much of the extreme poverty is concentrated in rural areas, and its large decline in the first half of the 80's was mainly as a result of the spurt in agricultural growth following decollectivization, land reform, and upward readjustment of farm procurement prices. These are mostly internal factors that had very little to do with global integration. Ravallion and Chen (2007) conclude from their analysis that "the score-card for trade reform is blank: we find no evidence that greater external openness was poverty reducing". In India, as an example, the N.S.S. data suggest that the rate of decline in poverty has, if anything, somewhat slowed down in 1993-05, the period of intensive opening of the economy, compared to the 70's and 80's. Thus, for reducing rural poverty one will need to give a closer look at why a large section of peasants have been marginalised in developing economies. 


\subsection{Educational Investment, Marginalisation and Social Exclusion: The Pathway from}

\section{Absolute Poverty to Destitution}

The traditional view of destitution is an extreme form of poverty that forces individuals to rely on social transfers like public and private charity, alms and welfare programs for survival. According to this view, destitution is created by a lack of ownership of relevant economic and social assets and skills of a specific group of people in a society. Destitution is usually related to non-working poverty (Dasgupta, 1993), which causes an "ill-being", or extreme and chronic deprivation, to people in terms of "basic physiological needs". For a destitute, destitution is nothing short of "personal calamity". In a rather emotive expression Drèze (2002) describes destitution as follows:

"There are millions of households in rural India that might be described as "destitute". These households typically have no able-bodied adult member and no regular source of income. They survive by doing a variety of informal activities such as gathering food from the village commons, making baskets, selling minor forest produce and keeping the odd goat" ${ }^{5}$.

I guess should be like this

"There are millions of households in rural India that might be described as "destitute". These households typically have no able-bodied adult member and no regular source of income. They survive by doing a variety of informal activities such as gathering food from the village commons, making baskets, selling minor forest produce and keeping the odd goat" ${ }^{\prime 6}$.

\footnotetext{
${ }^{5}$ Dreze Continues, "We were shocked to find that even in prosperous villages some households lived in conditions of extreme poverty and hunger. A casual visitor is unlikely to notice them, as destitute households keep a low profile and are often socially invisible. But if you look for them, you will find them, quietly struggling to earn their next meal or patiently starving in a dark mud hut. Destitute households are beyond the pale of most development programmes and welfare schemes”.

${ }^{6}$ Dreze Continues, "We were shocked to find that even in prosperous villages some households lived in conditions of extreme poverty and hunger. A casual visitor is unlikely to notice them, as destitute households keep a low profile and are often socially invisible. But if you look for them, you will find them, quietly struggling to earn their next meal or patiently starving in a dark mud hut. Destitute households are beyond the pale of most development programmes and welfare schemes”.
} 
The crux of our finding is that we marshal some evidence that destitution has spread from "households with no able-bodied adult members and no regular source of income" to the working poor who are regularly employed in the informal sector in Bangladesh. It is likely that a similar situation has arisen in many developing nations - especially in the Indian subcontinent. The key to the problem is educational investment, or lack of it. A family that invests adequately in education will escape from extreme form of poverty, or destitution. A family with inadequate investment in education will be trapped into some form of extreme poverty. It hence begs of a serious question about the determinants of educational investment by a family. Ours is a first attempt to understand the factors that motivate a family to acquire sufficient education to break away from the shackles of deep/extreme poverty, or destitution.

Our intuition is closely rooted to the powerful observation of Sen (2000) that social exclusion can be caused by social inclusion - an apparent contradiction in terms - that is based on "unfair terms". In other words, in the era of globalisation working poverty has created a new class of workers many of whom are reduced to destitution in developing nations despite their regular streams of earnings from the labour market. Destitution of some workers arises due to unfair terms in the labour markets of the informal sector in many developing nations. Our work shows that educational investment plays a crucial role for workers to avoid destitution. We also highlight the factors that enable and motivate workers to invest in education in order to break away from the traps of poverty and destitution. Our work establishes how decisions of others can cause and perpetuate destitution by influencing the individual decision to invest in education. 


\subsection{Related Literature: Destitution, Social Exclusion and Social Inclusion}

A starting point for defining a workable measure of extreme poverty, or destitution, comes from a distinction between the "poor" and the "ultra-poor" (see Lipton, 1988) ${ }^{7}$. The "ultrapoor" or "absolutely poor" fail to acquire their minimum subsistence needs, despite spending 80 per cent or more of their incomes on food (Lipton, 1988). Closely related to this approach is the World Bank's "dollar a day" definition of extreme poverty. The definition of extreme poverty in terms of kilocalorie food consumption has a similar intuition. The main problem with this approach is the arbitrary cut-off point below which an individual is considered a destitute. A more sophisticated definition of destitution is based on the labour market status of an individual as Dasgupta (1993) came to identify exclusion from the labour market as a cause as well as a manifestation of destitution. A further characterisation calls forth the inclusion of other assets, besides human capital and skills, for defining destitution (see Sen, 1981). The sociological definition of destitution requires social characterisation in addition to economic characteristics as highlighted before. Harriss-White (2002) explains destitution as 'an economic, social and political phenomenon'. From the above discussion it is important to note that destitution is a multidimensional concept: first and foremost, the failure to acquire the "basic needs" is an important component of destitution. Secondly, the degree of exclusion from, or failure to have access to, various markets like credit and labour markets and local public services, e.g. health services, also signifies the level of destitution of a group of people. Finally, the degree of discrimination in building human capital - that can perpetuate exclusion in other markets - will also play an important role in excluding various opportunities to a group of people. It is hence required to combine various sources of destitution to form a workable index of destitution. The crux of the matter is that destitution arises due to social exclusion, which is often caused by inadequate educational investment.

\footnotetext{
${ }^{7}$ The poor are those households who are unable to meet their minimum subsistence needs despite spending 60 per cent or more of their incomes on food.
} 
Our work unravels some interesting aspects of the social causes behind inadequate (educational) investment and consequent destitution.

\subsection{Social Interactions: Conformity and Deviance in Economics}

In economics social interactions take place whenever an agent's return is a function not only of his own action but also depends on the actions of other agents (Townsend, 1983). There is an extant literature on the relevance of social interactions for economic behaviour in a wide range of contexts. As an example, Benabou (1993) considers social interactions in neighbourhoods with regards to education and crime. Diamond (1982) examines social interactions in thick market externalities in trading. The existing literature has shown social interactions can have a wide range of effects on the properties of the economic equilibrium: social interactions can lead either to conformity of behaviour or to polarized actions (Bernheim, 1994). Social interactions can also give rise to multiple equilibria in the absence of which the equilibrium would otherwise be unique (Cooper and John, 1988). Cooper and Haltiwanger (1996) argue how social interactions can also propel the dynamics, or time profile, of an economic system.

The basic intuition of our paper is rooted to the recognition that education, in a classroom environment and outside classrooms, is a public good that is full of social interaction effects. From the education literature for schools we also know that social scientists have utilised the public good nature of classroom environment and underscored the congestion effect of class size and the peer effects on the learning outcomes of students - as in a classic paper by Lazear $(2001)^{8}$. The possible effect of peers and social learning for (acquired) individual behaviour is a contested phenomenon. There is a long tradition

\footnotetext{
${ }^{8}$ Empirical studies of peer effects in the school context have three known limitations: proper definition of a peer group, omitted variable bias due to self-selection into a group and common teacher effects that affect all members of a group (correlated effects), and the reflection problem (Manski 1993).
} 
among economists to unravel effects of peers on individual behaviours. In school participation decisions economists explain how individual choice is shaped by group behaviour (see Cipollone and Rosolia, 2007; Gaviria and Raphael, 2001; Bobonis and Finan, 2009). In labour markets economists highlight the influence of peer pressure on worker productivity (Mas and Moretti, 2009). In career games, we now know the impact of peer effect on choice of medical school specialisation (Arcidiacono and Nicholson, 2005). We also know how individual superannuation (retirement savings) behaviour is influenced by peer monitoring (Duflo and Saez, 2003). However, there are two related problems in the existing literature: first, a major problem in the literature is the inadequacy of the econometric techniques in identifying social interactions (see Brock and Durlauf, 2000 and 2001; Moffitt, 2001). A more serious problem is the ad-hoc manner in which peer groups are often defined in order to understand conformity or deviance (see Foster, 2006 and Moffitt 2001). These are recognised weaknesses in the existing literature and we do not intend to resolve them in this paper (see Hanushek et al., 2003). In these models social interactions are exogenous.

Banerjee (1992) offers a case of endogenous social interactions in a sequential decision making framework wherefrom a special form of social interactions, namely herd behaviour, arises endogenously. As opposed to herd behaviour, our context highlights exogenous social interactions. Herd behaviour in sequential investment decisions is a wellreceived doctrine. Scharfstein and Stein (1990) modelled sequential investment by agents/investors who care for their reputation as good forecasters. If these agents have correlated signals conditionally on the state of the world, investors will imitate, or copy, the behaviour of the first investor. This kind of modelling has come to be known as reputation herding ${ }^{9}$. In models of statistical herding, introduced by Banerjee (1992), and Bikhchandani et al. (1992), agents maximise expected returns/profits in a common value environment and

\footnotetext{
${ }^{9}$ Note that reputational herding is feasible if better agents have more correlated signals on the state of the world. Without this correlation followers would have little incentives to copy predecessors' behaviour. However, Ottaviani and Sorensen (2002) have shown that this correlation is not necessary except in the degenerate case.
} 
observe conditionally independent private signals of bounded precision, while still having access to watch the behaviour of others. Gradually, the accumulated evidence from observing earlier decisions is sufficiently strong to undermine the private information of a single decision-maker. The question about the source of herding begs an answer. Herding arises because the observed behaviour of other investors affects the probability belief attached to different states of the world and also the payoff conditional on each state for an individual investor. Banerjee (1992), Bikhchandani et el. (1992) and a large number of papers have shown the significance of informational cascades in modern investment markets. An informational cascade connotes a situation in which subsequent agents, based on the observations of others, makes the same choice independent of their private signals. Informational cascades are argued to engender erroneous mass behaviour and cause fragility in capital formation. In all these models the authors displayed a tendency to 'herd' in their modelling techniques, maybe due to reputational concerns - or otherwise: a decisionmaking agent has a private signal about the state of the world, and the accuracy of this signal is predicated upon one's ability. There is publicly available information summarised as a public prior, which determines the likely state of the decision-making environment/world. The agent chooses an action on the basis of this public prior and one's own private information, or signals. There is a peer who observes the state of the world, the public prior, and the set of chosen actions by a multitude of agents. The peer can assess the quality of the agents' private information, which sheds light on an agent's ability. The decision-making agent's payoff depends on the assessment of the peer and s/he, hence, chooses to 'herd' in order to avoid being assessed as an agent of less ability, or 'dumb'.

In a broader sense, our paper explains the context that embodies the 'influence which the characteristics and behaviours of one's reference groups has on one's assessments of alternative courses of behaviour (Durlauf, 1999, pp.2). Bowles (1999) spells out the attributes (such as trust, commitment, adherence to social norms and retributions to violators) that constitute the source of conformity that is in consonance with Putnam's initial 
idea of social capital (Putnam, 1993). These attributes dictate inter-relationships among people wherefrom a course of actions gets chosen. The existing literature also highlights the possibility that social behaviours can be copied, or replicated, by agents over time in an evolutionary manner. Agents have an incentive to update their strategies if current strategies fail to yield an average return. This leads to the possibility of self-selection of an equilibrium - either conformity or deviance. Our main contribution is to explain the causal factors that guide agents to select one of the two possible equilibria (conformity or deviance), which creates the poverty trap in our model. Following Taylor and Jonker (1978) one can presume that agents are programmed to play pure strategies. At this stage, our context is static. In our future work, we will examine the dynamics by focusing upon the educational investment of households over time. For undertaking this study we will develop a relevant panel data from the chosen households.

\section{Conclusion}

In many economic decision-making, individuals are influenced by decisions of others. As an example, the fashion industry thrives on the impact/influence of the group behaviour upon individual decisions (see Clark and Oswald, 1998; Akerlof, 1980 among many). We now know that similar influences impinge on technology adoption, purchase and sales of assets and individual investment dynamics ${ }^{10}$. From a series of work on poverty we also know that poverty traps are created and perpetuated by informational herding (see Banerjee and Duflo, 2011). In poorer countries people can avoid, or overcome, property traps by investing in

\footnotetext{
${ }^{10}$ Two phenomena are of particular interests to the profession, namely informational cascades and herd behaviour that can arise in several circumstances. Despite the fact that herd behaviour and informational cascades are interchangeably used in the existing literature, there is a significant difference in their precise imports. Informational cascades describe an infinite sequence of individual decisions in which individuals ignore their private information while making a decision. In herding an infinite sequence of individuals make an identical decision (see Smith and Sorensen, 2000). Herding thus implies that individuals choose the same action in a given circumstance, but they may have acted differently from one another if the realization of their private signals had been different. In this paper we focus solely upon herd behaviour, or herding.
} 
education. In acquiring education people are driven by direct benefits from education and also by comparison utility, or social status, which indicates some sort of herding. In this paper we chose a simple comparison utility function that enables us to gain rare insights into poverty traps and educational investment by using live data from a field survey undertaken in Bangladesh. These insights are three-fold: first, the simple comparison utility function enables us to dichotomise agents into two mutually exclusive groups - those who are actuated by virtuous herding vis-a-vis those who are propelled by vicious anti-herding, or social deviancy. The herding is virtuous since agents invest in education in excess of their reference group average, which can dismantle the poverty traps. The social deviance is vicious since it has the potential to perpetuate the poverty of those agents who choose to anti-herd. Secondly, from the field study we are able to isolate those who herd from those who anti-herd in terms of their decision to invest in education. Finally, from the individual and household characteristics we are able to predict what causes the cleavage in the behaviour of agents between social copying and social deviancy. 


\section{Appendix 1:}

In Prakash et al. (1998) introduced a cubic utility function in terms of wealth which, according to them, captures risk aversion for a decision-maker and yet allows a preference for unfair gambles (see Horowitz, 1998). It is well-known that the cubic utility function can be only locally risk-averse, and our model therefore can address local risk-aversion. By choosing a cubic utility function we exclude the possibility of global risk aversion. This is important for our research since global risk aversion will imply that no agents will ever choose an unfair gamble and, hence, never overcome the poverty trap by investing in education. As a result, we will need to choose a utility function that displays non-global risk aversion, which will introduce a preference for unfair gambles. Quiggin (1993) argues that the expected utility theory will have to assume local risk aversion - and not global risk aversion - for explaining risk-taking behaviour. From Quiggin (1993) we also know that one will need to introduce a non-expected utility theory, namely, the Rank Dependent Expected Utility theory - if one wants to avoid the assumption of local risk aversion. Thus, our postulated utility function is in consonance with the existing literature on expected utility theory. In their pioneering work Friedman and Savage (1948; 1952) chose a similar formulation of the utility function being locally risk-averse: they assumed the utility function to display risk aversion for low levels of wealth. Beyond a critical level of wealth, the same decision maker becomes risk-loving. The same decision-maker becomes risk-averse again beyond another threshold level of wealth. The expected utility theory is thus predicated upon local risk aversion and our utility function has the same feature. From the postulated comparison utility function we know:

$V\left(K^{*}-K_{i}\right)=\left[\left(K^{*}-K_{i}\right)^{3} / 3\right]+K_{0}$

$V^{\prime}\left(K_{i}, K^{*}\right)=\left(K^{*}-K_{i}\right)^{2}>0$

$V^{\prime \prime}\left(K_{i}, K^{*}\right)=2\left(K^{*}-K_{i}\right)$

We thus note the following from the utility function:

OBSERVATION1: Since $V^{\prime}\left(K_{i}, K^{\star}\right)>0$, the comparison utility function is an increasing function at an increasing rate in $\mathrm{K}_{\mathrm{i}}$, if $\mathrm{K}^{*}>\mathrm{K}_{\mathrm{i}}$. For $\mathrm{K}_{\mathrm{i}}<\mathrm{K}^{\star}$, the decision-maker is risk-loving. In other words, for $\mathrm{K}_{\mathrm{i}}<\mathrm{K}^{*}$, the decision-maker is locally risk-loving. For $\mathrm{K}_{\mathrm{i}}>\mathrm{K}^{\star}$, the comparison utility function displays local risk-aversion as it is concave in $\left(\mathrm{K}^{*}-\mathrm{K}_{\mathrm{i}}\right)$. Thus, by construction, the comparison utility function changes its slope at $\mathrm{K}^{*}$. Note from Diagram 1 , Friedman and Savage $(1948 ; 1952)$ postulated one additional segment to our utility function: they also added a concave part to the right after the convex part beyond a threshold, which is rather ad hoc.

We plot our utility curve in Diagram 1 by writing $\mathrm{k}=\mathrm{K} * / \mathrm{K}_{\mathrm{i}}$ 
DIAGRAM 1: POSTULATED SHAPE OF THE UTILITY FUNCTION

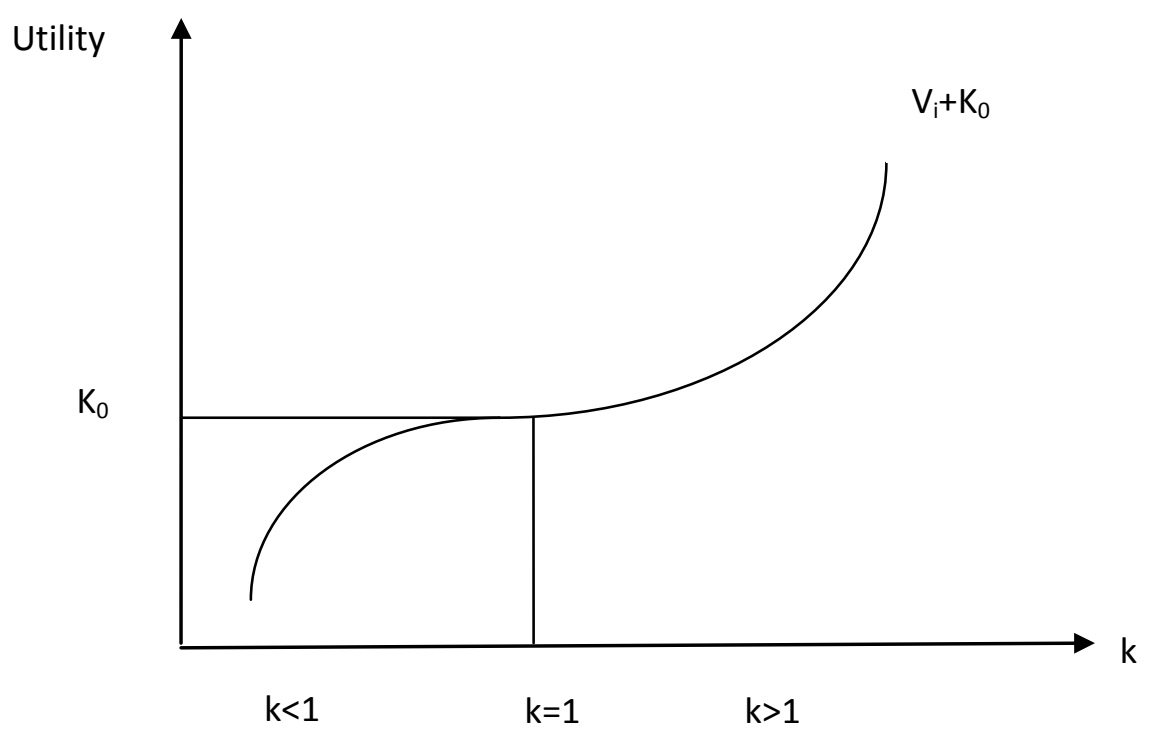




\section{References:}

Akerlof, G.A., 1980. A Theory of Social Custom, of Which Unemployment May be One Consequence. Quarterly Journal of Economics 94, 749-775.

Arcidiacono, Peter and Sean Nicholson. 2005. Peer Effects in Medical School. Journal of Public Economics, 89(2-3): 327-350.

Bardhan, P. K. 2010. Awakening Giants, Feet of Clay: Assessing the Economic Rise of China and India. MIT Press.

Banerjee, A. V. and E. Duflo. 2011. Poor Economics: A Radical Rethinking of the Way to Fight Global Poverty, Random House, New Delhi.

Banerjee, A. V. 1992. A Simple Model of Herd Behavior. Quarterly Journal of Economics, Vol. 107(3), pp. 797-818.

Bikhchandani, S., D. Hirshleifer, I. Welsh. 1992. A Theory of Fads, Fashion, Custom, and Cultural Change as Informational Cascades, Journal of Political Economy, 100:5, pp. 9921026.

Benabou, R., 1993. Workings of a City. Quarterly Journal of Economics, 108, pp. 619-652.

Bernheim, D., 1994. A Theory of Conformity, Journal of Political Economy, 102, pp. 841-877.

Blau, Peter M. 1964. Exchange and Power in Social Life. New York: Wiley.

Bobonis, Gustavo J. and Frederico Finan. 2009. Neighborhood Peer Effects in Secondary School Enrollment Decisions. Review of Economics and Statistics, 91(4): 695-716.

Brock, W. and S. Durlauf. 2001. Discrete Choice with Social Interactions, Review of Economic Studies, 68, 235-260.

Brock, W. and S. Durlauf. 2000. Interactions Based Models, in Handbook of Econometrics, ed. by J. Heckman and E. Learner. Amsterdam: North-Holland.

Bowles S., 1999. Social Capital and Community Governance, Focus, vol. 20 pp.6-10. 
Bowles, S., and H. Gintis, 1988. Contested Exchange: Political Economy and Modern Economic Theory, American Economic Review, 78, pp. 145-150.

Chen, S. and Ravallion, M. 1996. Data in Transition: Assessing Rural Living Standards in Southern China. China Economic Reviews, 7(1):23-56.

Cipollone and Rosolia, 2007. Social Interactions in High School: Lessons from an Earthquake, American Economic Review, 97(3): 948-965.

Clark, A.E., Oswald, A.J. 1998. Comparison-Concave Utility and Following Behaviour in Social and Economic Settings. Journal of Public Economics, 63, 232-45.

Clark, A.E., Oswald, A.J. 1996. Satisfaction and Comparison Income. Journal of Public Economics, 61, 359-381.

Cooper, R. and J. Haltiwanger, 1996. Evidence on Macroeconomic Complementarities. Review of Economic and Statistics, 78, pp. 78-93.

Cooper, R. and A. John, 1988. Coordinating Coordination Failures in Keynesian Models. Quarterly Journal of Economics, 103, pp. 441-463.

Dasgupta, P., 1993. An Inquiry into Well-Being and Destitution, Oxford: Clarendon Press. Diamond, P. A., 1982. Aggregate Demand Management in Search Equilibrium. Journal of Political Economy, 90, pp. 881-894.

Drèze, J., 2002. Food transfers to the destitute are a good way of using the surplus grain stocks, The Hindu, 29 July 2002.

Duflo, Esther and Emmanuel Saez, 2003. The Role of Information and Social Interactions in Retirement Plan Decisions: Evidence from a Randomized Experiment. Quarterly Journal of Economics 118(3): 815-842.

Durkheim, Émile. (1893) 1964. The Division of Labor in Society. Translated by George Simpson. New York: Free Press.

Durlauf, S., 1999. The Case against Social Capital. Focus vol. 20, pp. 1-5. 
Dutt, G. and Ravallion, M. 2002. Has India's Post-reform Economic Growth Left the Poor Behind?, Journal of Economic Perspectives, 16(3).

Foster, Gigi. 2006. It's Not Your Peers, and It's Not Your Friends: Some Progress Toward Understanding the Educational Peer Effect Mechanism. Journal of Public Economics 90(89): $1455-1475$.

Frank, R.H., 1984a. Are Workers Paid Their Marginal Products? American Economic Review, 74, 549-571.

Frank, R.H., 1984b. Interdependent Preferences and the Competitive Wage Structure. Rand Journal of Economics, 15, 510-520.

Frank, Robert H. 1985. Choosing the Right Pond, Human Behavior and the Quest for Status. New York, Oxford University Press.

Friedman, M., \& Savage, L. J. 1948. The utility analysis of choices involving risk. Journal of Political Economy, 56(4), 279-304.

Friedman, M., \& Savage, L. J. 1952. The expected utility hypothesis and the measurability of utility. 60(6), 463-486.

Fujita, M 2006. Economic Development Capitalizing on Brand Agriculture: Turning Development Strategy on its Head, Paper Presented at the World Bank Annual Conference on Development Economics in Tokyo, May 29-30, 2006.

Fujita, M and N. Hamaguchi 2007. Brand Agriculture and Economic Geography: A General Equilibrium Analysis, Discussion Paper 207, Kobe University.

Fujita, M. (ed.) 2005. Spatial Economics. In the series of the International Library of Critical Writings in Economics. Cheltenham, UK: Edward Elgar.

Fujita, M. (ed) 2007. Regional Integration in East Asia. UK: Palagrave Macmillan.

Galenson, Walter, and Harvey Leibenstein. 1955. Investment Criteria, Productivity, and Economic Development, Quarterly Journal of Economics 80 (August): 342-370. 
Gaviria, Alejandro and Steven Raphael. 2001. School-Based Peer Effects and Juvenile Behavior. The Review of Economics and Statistics, 83(2): 257-268.

Hanushek, Eric A., John F. Kain, Jacob M. Markman, and Steven G. Rivkin, 2003. Does Peer Ability Affect Student Achievement? Journal of Applied Econometrics 18(5): 527-544.

Harriss-White, B., 2002. A Note on Destitution, QEH Working Paper 86, Oxford: Queen Elizabeth House, University of Oxford CN).

Horowitz, I. 1998. Will a risk-averse decision maker ever really prefer an unfair gamble? Decision Sciences, 29(2), 517-520.

Hirschman, A. O. 1958. The Strategy of Development (Yale University Press, New Haven, $\mathrm{CN})$

James, William. (1891) 1952. The Principles of Psychology. Chicago, Britannica.

Jasso, G. 2001. Studying Status: An Integrated Framework. American Sociological Review, 66:96-124.

Jones, S.R.G., 1984. The Economics of Conformism. Blackwell, Oxford.

Kakwani, Nanak, Shahid Khandker and Hyun H. Son. 2004. Pro-Poor Growth: Concepts and Measurements with Country Case Studies. Working Paper of the International Poverty Centre, Brasilia, August.

Kanbur, R. and Zhang, X.B. 2003. Fifty Years of Regional Inequality in China : A Journey Through Central Planning, Reforms and Openness". Paper prepared for UNU/WIDR projects conference on spatial inequality in Asia, Tokyo, 29-29 March 2003.

Kanbur, R 2005. Growth, Inequality and Poverty: Some Hard Questions, Journal of International Affairs, 58(2), 223-235.

Kandel, E., Lazear, E.P., 1992. Peer Pressure and Partnerships. Journal of Political Economy, 100, 801-817. 
Lazear, Edward P. 2001. Educational Production. Quarterly Journal of Economics, 116(3): 777-803.

Lenoir, René. 1974/1989. Les Exclus: Un Francais sur Dix. Paris: Editions du Seuil.

Levitas, R. 1998. The Inclusive Society? Social Exclusion and the New Labour, Macmillan, London.

Levy, G. 2004. Anti-Herding and Strategic Consultation. European Economic Review, 48, pp. 503-525.

Lipton, M. 1988. The Poor and the Poorest, Discussion Paper 25, Washington, D.C.: World Bank

Manski, Charles. 1993. Identification of Endogenous Social Effects: The Reflection Problem. Review of Economics Studies. 60(3): 531-542.

Manski, Charles F.1995. Identification Problems in the Social Sciences. Harvard University Press.

Mas, Alexandre and Enrico Moretti. 2009. "Peers At Work," American Economic Review, 99(1): 112-145.

Marx, Karl. (1849) 1968. Wage Labour and Capital. pp. 74-97 in Karl Marx and Frederick Engels: Selected Works. New York: International Publishers.

Moffitt, Robert. 2001.Policy Interventions, Low-Level Equilibrium, and Social interactions. In S. Durlauf and P. Young (eds.), Social Dynamics. Cambridge, MA: MIT Press.

Ottoviani, M. and Sorensen, P. 2000. Herd Behaviour and Investment: A Comment. American Economic Review, 90, pp. 695-704.

Prakash A.J., Chang, C. H., Hamid, S., \&Smyser, M. W. 1998. Will a risk-averse decision maker ever really prefer an unfair gamble? Sometimes, he will. Decision Sciences, 29(2), $521-524$.

Putnam, R., 1993. The Prosperous Community: Social Capital and Public Life. The American Prospect, vol. 13, pp. 35-42. 
Quiggin, J. 1993. Generalized Expected Utility Theory: The Rank-Dependent Model. Kluwer Academic Publishers, Boston.

Ravallion, M. 1997. Can High Inequality Development Countries Escape Absolute Poverty?, Economics Letters, 56, pp. 51-57.

Ravallion, M. and Chen, S., 2007. Absolute Poverty Measures for the Developing World 1981-2004, World Bank Policy Research Working Paper No. 4211.Washington D.C.: World Bank.

Ravallion, M. 2004. Pro-Poor Growth: A Primer. The World Bank, Policy Research Working Paper No. 3242.

Ravallion, Martin and Shaohua Chen. 2003. Measuring Pro-Poor Growth. Economic Letters, Vol. 78, pp. 93-99.

Runciman, William G. 1961. Problems of Research on Relative Deprivation. Archives Européennes de Sociologie 2:315-323.

Scharfstein, D., and Stein, J. 1990. "Herd Behaviour and Investment", American Economic Review, Vol. 80, pp. 465-479.

Sen, A.K. 1981. Poverty and Famines: An Essay on Entitlement and Deprivation. Oxford: Clarendon Press.

Sen, A.K. 1985. Commodities and Capabilities, Amsterdam: North-Holland.

Sen, A.K. 1997. Inequality, Unemployment and Contemporary Europe. International Labour Review 136 (2): 155-72.

Sen, A.K. 1999. Development as Freedom, Oxford: Oxford University Press

Sen, A. K.2000. Social Exclusion, Concept, Application, and Scrutiny, Social Development Papers No. 1, Asian Development Bank, June 2000.

Shawn, F., Rachel, G., and Margy, W. 2007. Social Inclusion for the United States, Center for Economic Policy and Research, 2007. 
Silver, H. 1994). Social Exclusion and Social Solidarity: three Paradigms, International Labour Review, vol. 133, no. 6, pp. 531-577.

Smith, L., and Sorensen, P. 2000. Pathological Outcomes of Observational Learning, Econometrica, 68(2), pp. 371-398.

The Hindu (2011). India, China Reduced Poverty Remarkably: MDG Report', July 8.

Taylor, P. and L. Jonker. (1978). Evolutionary Stable Strategies and Game Dynamics, Mathematical Bioscience, 40 pp. 145-56.

Townsend, R.M. 1983. Forecasting the Forecasts of Others. Journal of Political Economy, $91,546-568$. 